\title{
Pendapat dan Pengalaman Peserta Pusat Kebugaran di Surabaya tentang Healthy Weight Management
}

Aulia Intan Firdaus*, Radika Ayu Prahesthi, Safira Indah Lestari, Ulfi Adianti Karunia, Ali Nur Ad Deen, Darwinda Pintowantoro, Vely Mandaoni, Clara Tissa Augusta, Sonia Marthalia Siregar, Lailya Nissa'us Sholihah, Mutiara Adisty Program Studi Pendidikan Apoteker, Fakultas Farmasi, Universitas Airlangga, Surabaya

*Corresponding author: aulia.intan.firdaus-2015@ff.unair.ac.id

\begin{abstract}
Background: Obesity is one of the causes of increasing mortality in the world. A total of 1.9 billion adults aged $>18$ years old were overweight of which 650 million are obese. Lifestyle and physical activities affect healthy weight management, pharmacist is a medical practitioner that easily accessed and have a knowledge about lifestyle, drugs, and disease. The profession has potential role in healthy weight management. Objective: This study aimed to identify the opinions and experiences about healthy weight management from people attended several fitness centers in Surabaya. Methods: This study was designed as a cross sectional research. Sampling was done by accidental sampling on 116 subjects with included criteria for people over the age of 18 and a fitness center users. The study was conducted using a questionnaire and was analyzed descriptively by Statistical Package for the Social Sciences (SPSS) Software. Results: The majority of the participant had various opinions and views about healthy weight management. Conclusion: To conclude pharmacists were considered as one of competent medical practitioners that can play a role in healthy weight management but for now pharmacist were not the main priority of health practitioner needed in consultation.
\end{abstract}

Keywords: obesity, overweight, healthy weight management, pharmacist

\begin{abstract}
Abstrak
Pendahuluan: Obesitas menjadi salah satu penyebab meningkatnya angka kematian di dunia. Sebanyak 1,9 milyar orang dewasa dengan usia lebih dari 18 tahun mengalami overweight dimana 650 juta diantaranya mengalami obesitas. Gaya hidup dan aktivitas fisik merupakan faktor yang dapat mempengaruhi berat badan seseorang, apoteker merupakan tenaga kesehatan yang mudah diakses dan memiliki pengetahuan tentang gaya hidup, obat, dan penyakit, sehingga berpotensi memberikan peran dalam healthy weight management. Tujuan: Penelitian ini bertujuan untuk mengetahui pendapat dan pengalaman masyarakat tentang healthy weight management yang ada di beberapa pusat kebugaran di Surabaya. Metode: Penelitian ini menggunakan desain penelitian deskriptif dengan pendekatan metode cross-sectional. Pengambilan sampel dilakukan secara accidental sampling pada 116 orang menjadi responden dengan kriteria inklusi masyarakat yang berusia di atas 18 tahun dan pengguna jasa pusat kebugaran. Penelitian dilakukan menggunakan kuesioner yang dianalisa secara deskriptif dengan bantuan Software Statistical Package for the Social Sciences (SPSS). Hasil: Dari hasil penelitian didapatkan bahwa responden memiliki pengetahuan dan pengalaman yang bervariasi tentang healthy weight management. Kesimpulan: Sebagian responden juga berpendapat bahwa apoteker dianggap dapat berperan dalam healthy weight management meskipun saat ini peran apoteker di Indonesia khususnya di Surabaya belum banyak terlihat pada program healthy weight management di apotek-apotek.
\end{abstract}

Kata kunci: obesitas, overweight, healthy weight management, apoteker

\section{PENDAHULUAN}

Pada tahun 2016, lebih dari 1,9 milyar orang dewasa usia lebih dari 18 tahun mengalami overweight dimana 650 juta orang diantaranya mengalami obesitas. Banyak penelitian mengungkapkan bahwa ada peningkatan angka kejadian kematian yang berkaitan dengan obesitas dan overweight (Behan \& Cox, 2010). Dalam penelitian yang melibatkan 894,576 partisipan dari Eropa Barat dan Amerika Utara, ditemukan bahwa angka kematian terkecil terjadi pada partisipan dengan rentang Body Mass Index (BMI) 22,5 sampai 25 (normal). Selain itu setiap peningkatan BMI sebanyak 
5 unit berkaitan dengan peningkatan tingkat bahaya untuk setiap penyebab kematian (Whitlock dkk., 2009).

Berdasarkan data Global Health Observatory (GHO), prevalensi orang dewasa di Indonesia dengan berat badan berlebih meningkat hingga $28,2 \%$ dari tahun 1975 hingga 2016.

Menurut World Health Organization (WHO), terdapat dua metode pendekatan perhitungan berat badan yaitu Body Mass Index (BMI) dan waist hip ratio. BMI $\left(\mathrm{Kg} / \mathrm{m}^{2}\right)$ dihitung dari berat badan $(\mathrm{Kg})$ dibagi dengan tinggi badan kuadrat $\left(\mathrm{m}^{2}\right)$. Kriteria BMI dibagi menjadi underweight $(<18,5)$, normal weight $(18,5$ - 24,9), overweight $(25,0$ - 29,9) dan obesity (> 30,0). Sedangkan pendekatan berat badan melalui waist hip ratio diukur dari lingkar pinggang, dinyatakan normal jika lingkar pinggang $<88 \mathrm{~cm}$ untuk wanita dan $<110 \mathrm{~cm}$ untuk pria (WHO, 2018).

Perilaku konsumsi memegang peran penting terhadap perubahan gaya hidup yang dapat memberikan efek buruk pada kesehatan terutama pada penduduk perkotaan. Menurut Chiolero dkk. (2008) merokok dapat meningkatkan berat badan atau memiliki resiko diabetes karena terjadi retensi insulin yang menyebabkan akumulasi lemak. Selain itu, konsumsi minuman beralkohol secara berlebihan dapat meningkatkan kadar kolesterol. Konsumsi makanan berlemak dapat mengakibatkan kegemukan karena memiliki lipid density yang tinggi, namun tidak mengenyangkan (Guallar-Castillón dkk., 2007). Menurut Rimbawan \& Siagian (2004) konsumsi makanan manis mengandung gula tinggi dapat memacu peningkatan gula darah sehingga menimbulkan rasa lapar dalam waktu cepat, apalagi pada era modern dengan kemajuan teknologi membuat orang semakin malas melakukan aktifitas fisik.

Overweight dan obesitas pada orang dewasa meningkatkan resiko dari mortalitas dan morbiditas terhadap banyak penyakit kronik, termasuk penyakit jantung koroner, hipertensi, dislipidemia, diabetes melitus, penyakit ginjal, dan beberapa tipe dari kanker. Di Amerika, rekomendasi untuk terapi dan pencegahan terhadap obesitas pada orang dewasa meliputi penggabungan diet sehat dan olahraga dengan modifikasi perilaku yang dirancang untuk pemeliharaan perubahan gaya hidup. Perilaku diet yang sehat peningkatan konsumsi buah dan sayuran, mengurangi konsumsi lemak makanan dan setidaknya 30 menit melakukan aktivitas fisik sedang setiap hari dalam seminggu serta melakukan aktivitas fisik berat yang melatih kardiorespirasi. Jenis-jenis latihan yang paling umum dilakukan pada kalangan wanita seperti berjalan dan aerobik, sedangkan untuk pria adalah berjalan dan latihan beban (Lowry dkk., 2000).

Anjuran WHO tahun 2005 untuk tindakan preventif kegemukan pada orang dewasa adalah melakukan aktivitas fisik berat atau olahraga rutin minimal 60 menit dan minimal 5 kali dalam seminggu. Aktivitas fisik yang praktis dilakukan antara lain: bersepeda menuju kantor, naik-turun tangga tanpa lift, jalan kaki beberapa kilometer pada saat berangkat atau pulang kantor, dan sebagainya. Sedangkan konsumsi sayuran dan buah yang dapat mencegah kegemukan dan dianjurkan Depkes (2007). Menurut Depkes, konsumsi sayur dan buah yang cukup yaitu lebih dari 5 porsi/hari selama 7 hari dalam seminggu atau menurut Almatsier (2004) konsumsi serat per hari yang baik adalah 25 gram/hari (Humayroh, 2009).

Peran apoteker dalam promosi kesehatan merupakan hal yang penting dalam mencegah terjadinya penyakit yang tidak diinginkan. Apoteker memiliki peran penting sebagai tenaga kesehatan terbanyak ketiga di dunia dengan tingkat kedisiplinan yang tinggi (Asmelashe dkk., 2017). Beberapa healthy weight management programs juga dapat ditawarkan oleh apoteker pada farmasi komunitas dimana dapat memberikan dampak yang baik pada kesehatan masyarakat (O’Neal \& Crosby, 2014). Selain itu, apoteker merupakan tenaga kesehatan yang mudah diakses oleh masyarakat dan memiliki pengetahuan dibidang obat-obatan, penyakit, dan perubahan gaya hidup. Apoteker juga dapat berkontribusi untuk healthy weight management program dengan cara melakukan skrining (Elliott dkk., 2015).

Banyak orang yang overweight kurang peduli terhadap berat badan sehingga enggan untuk menjaga berat badan baik dengan mengatur pola makan atau olahraga (Brener dkk., 2004). Menurut penelitian Olaoye \& Oyetunde (2012), menemukan bahwa ada banyak orang yang kurang peduli terhadap berat badan dan ini menjadi hambatan untuk merubah gaya hidup orang tersebut untuk menjadi lebih baik. Sebuah survei yang dilakukan di Malaysia menunjukkan bahwa dari 730 orang yang mengunjungi pusat kebugaran, sebanyak $63,2 \%$ merasa overweight dan $21 \%$ merasa obesitas (Verma dkk., 2018). Menurut hasil penelitian di atas, peneliti memutuskan pusat kebugaran sebagai objek penelitian karena sebagian besar orang yang pergi ke pusat kebugaran adalah mereka yang peduli terhadap berat badannya.

Berdasarkan latar belakang diatas pada penelitian ini ingin diketahui bagaimana pendapat dan pengalaman pengunjung pusat kebugaran tentang 
healthy weight management dan peran apoteker dalam pelaksanaan program healthy weight management di Apotek.

\section{METODE}

\section{Desain penelitian}

Penelitian ini didesain secara cross-sectional yang bertujuan untuk mengetahui pendapat dan pengalaman peserta pusat kebugaran tentang healthy weight management di wilayah Surabaya Timur, Indonesia. Pengambilan data dilakukan selama bulan September 2018.

Pengambilan sampel dilakukan secara accidental sampling dengan total jumlah responden sebanyak 116 orang. Kriteria inklusi adalah masyarakat yang berusia di atas 18 tahun dan pengguna jasa pusat kebugaran.

\section{Instrumen survei}

Kuesioner dirancang berdasarkan telaah literatur terkait healthy weight management dan pelayanan yang tersedia di apotek. Kuesioner terdiri dari 34 pertanyaan yang terbagi dalam 9 kategori pertanyaan meliputi data demografi, pendapat responden tentang metode efektif untuk menurunkan berat badan, prioritas profesi untuk konsultasi mengontrol berat badan, hal yang diperlukan untuk mengatasi obesitas, kondisi responden terkait pola hidup sehat, produk atau pelayanan mengontrol berat badan di apotek yang pernah dilihat atau digunakan, aktivitas fisik yang dilakukan responden dalam satu minggu serta pendapat responden tentang pelayanan menjaga berat badan yang sehat oleh apoteker. Tanggapan dari responden dicatat dalam bentuk skala Likert lima poin ( $1=$ sangat tidak setuju, 2 = tidak setuju, $3=$ netral, $4=$ setuju dan $5=$ sangat setuju) atau pilihan jawaban ya, tidak, dan tidak tahu. Pada bagian prioritas untuk konsultasi, responden diminta untuk memberikan peringkat prioritas untuk konsultasi tentang mengontrol berat badan dari profesional tenaga kesehatan seperti ahli gizi, dokter, apoteker, perawat, instruktur kebugaran atau staf slimming center. Pada bagian produk atau pelayanan mengontrol berat badan yang ada di apotek baik yang pernah dilihat atau digunakan, responden diminta untuk memilih dan diperbolehkan memilih lebih dari satu pilihan.

Sebagian pertanyaan dalam kuesioner diadaptasi dari jurnal penelitian yang dilakukan oleh Verma dkk. (2018) dan dari Lin dkk. (2016). Validitas rupa kuesioner dilakukan sebelum pengambilan data di lapangan.

Data dikumpulkan melalui kuesioner yang diisi langsung oleh responden. Kuesioner diberikan kepada responden yang berada di pusat kebugaran di Surabaya. Ada sembilan pusat kebugaran di Surabaya yang menjadi tempat penyebaran kuesioner. Responden juga diberikan informasi tentang latar belakang survei dan tujuannya sebelum mengisi kuesioner. Partisipasi dalam survei ini adalah sukarela dan persetujuan tertulis (informed consent) diperoleh dari responden sebelum pengumpulan data.

Data dianalisis secara deskriptif dan untuk masingmasing variabel pertanyaan disajikan dan data demografi dalam bentuk tabel dan persentase. Pengolahan data dilakukan dengan bantuan Software Statistical Package for the Social Sciences (SPSS) versi 22.0 .

\section{HASIL DAN PEMBAHASAN Demografi responden}

Data demografi dari responden dapat dilihat pada Tabel 1. Lebih dari separuh responden adalah perempuan, meskipun hasil penelitian ini belum dapat menggambarkan adanya perbedaan gender dalam program healthy weight management. Menurut penelitian yang dilakukan oleh Lowry dkk. (2000) sebanyak $55 \%$ wanita dan $45 \%$ pria berupaya untuk menurunkan berat badan dengan mengubah pola makan dan berolahraga. Data demografi juga menunjukkan lebih dari lima puluh persen responden memiliki berat badan yang tidak normal (overweight dan obesitas) dan sebagian besar responden belum pernah mengkonsultasikan berat badannya kepada tenaga kesehatan profesional yang ada (Tabel 1). 
Tabel 1. Demografi responden

\begin{tabular}{|c|c|c|}
\hline Data & \multicolumn{2}{|c|}{$\mathrm{n}(\%) / \mathrm{Mean} \pm \mathrm{SD}$} \\
\hline \multicolumn{3}{|l|}{ Jenis Kelamin } \\
\hline Laki-laki & \multicolumn{2}{|c|}{$20(17,2 \%)$} \\
\hline Perempuan & \multicolumn{2}{|c|}{$96(82,8 \%)$} \\
\hline Berat Badan & \multicolumn{2}{|c|}{$60,8 \pm 14,3$} \\
\hline Tinggi Badan & \multicolumn{2}{|c|}{$160,5 \pm 7,5$} \\
\hline BMI & \multicolumn{2}{|c|}{$23,2 \pm 4,4$} \\
\hline Kondisi Responden & Pendapat & Kalkulasi* \\
\hline Underweight & $8(6,9 \%)$ & $13(11,2 \%)$ \\
\hline Normal Weight & $58(50,0 \%)$ & $68(58,6 \%)$ \\
\hline Overweight & $48(41,4 \%)$ & $27(23,3 \%)$ \\
\hline Obese & $2(1,7 \%)$ & $8(6,9 \%)$ \\
\hline \multicolumn{3}{|l|}{ Pendidikan terakhir } \\
\hline SMP/Sederajat & \multicolumn{2}{|c|}{$3(2,5 \%)$} \\
\hline SMA/Sederajat & \multicolumn{2}{|c|}{$69(59,5 \%)$} \\
\hline D1/D2/D3/D4 & \multicolumn{2}{|c|}{$8(6,9 \%)$} \\
\hline $\mathrm{S} 1 / \mathrm{S} 2 / \mathrm{S} 3$ & \multicolumn{2}{|c|}{$36(31 \%)$} \\
\hline \multicolumn{3}{|l|}{ Pekerjaan } \\
\hline Tidak bekerja & \multicolumn{2}{|c|}{$43(37,1 \%)$} \\
\hline Ibu rumah tangga & \multicolumn{2}{|c|}{$9(7,8 \%)$} \\
\hline Wiraswasta & \multicolumn{2}{|c|}{$15(12,9 \%)$} \\
\hline Pekerja swasta & \multicolumn{2}{|c|}{$32(27,6 \%)$} \\
\hline Pegawai negeri sipil & \multicolumn{2}{|c|}{$1(0,9 \%)$} \\
\hline Lain-lain & \multicolumn{2}{|c|}{$16(13,8 \%)$} \\
\hline \multicolumn{3}{|l|}{ Pendapatan per bulan } \\
\hline$<\operatorname{Rp} 3.500 .000$ & \multicolumn{2}{|c|}{$70(60,3 \%)$} \\
\hline Rp 3.500.000 - Rp 7.000.000 & \multicolumn{2}{|c|}{$40(34,5 \%)$} \\
\hline$>\operatorname{Rp} 7.000 .000$ & \multicolumn{2}{|c|}{$6(5,2 \%)$} \\
\hline \multicolumn{3}{|l|}{ Pernah Melakukan Konsultasi } \\
\hline Ya & \multicolumn{2}{|c|}{$46(39,7 \%)$} \\
\hline Tidak & \multicolumn{2}{|c|}{$70(60,3 \%)$} \\
\hline
\end{tabular}

Hasil data prioritas menunjukkan sebagian besar responden yang diminta mengurutkan prioritas untuk konsultasi tentang berat badan lebih memilih menempatkan dokter pada prioritas pertama $(34,5 \%)$, diikuti oleh instruktur fitness $(25,0 \%)$, ahli gizi $(24,1 \%)$, dan staf slimming centre $(9,5 \%)$. Hanya $2,6 \%$ responden yang memilih apoteker sebagai prioritas utama (Tabel 2). Hal ini kemungkinan bisa disebabkan karena masyarakat kurang mengenal peran apoteker terutama dalam healthy weight management. Prioritas pertama ditempati oleh dokter karena mindset mayoritas dari masyarakat terkait kesehatan identik dengan dokter, termasuk dalam hal berat badan. 
Tabel 2. Prioritas pemilihan profesi untuk konsultasi healthy weight management

\begin{tabular}{lcccccc}
\hline \multirow{2}{*}{ Profesi } & \multicolumn{5}{c}{ Urutan prioritas } \\
\cline { 2 - 7 } & 1 & 2 & 3 & 4 & 5 & 6 \\
\hline Ahli gizi & $18(24,1 \%)$ & $29(25,0 \%)$ & $27(23,3 \%)$ & $20(17,2 \%)$ & $4(3,4 \%)$ & $7(6,0 \%)$ \\
\hline Dokter & $40(34,5 \%)$ & $19(16,4 \%)$ & $15(12,9 \%)$ & $35(30,2 \%)$ & $3(2,6 \%)$ & $3(2,6 \%)$ \\
\hline Apoteker & $3(2,6 \%)$ & $7(6,0 \%)$ & $10(8,6 \%)$ & $17(14,7 \%)$ & $60(51,7 \%)$ & $18(15,5 \%)$ \\
\hline Perawat & $2(1,7 \%)$ & $8(6,9 \%)$ & $10(8,6 \%)$ & $12(10,3 \%)$ & $23(19,8 \%)$ & $60(51,7 \%)$ \\
\hline $\begin{array}{l}\text { Instruktur } \\
\text { fitness }\end{array}$ & $29(25,0 \%)$ & $32(27,6 \%)$ & $35(30,2 \%)$ & $8(6,9 \%)$ & $8(6,9 \%)$ & $3(2,6 \%)$ \\
\hline $\begin{array}{l}\text { Slimming } \\
\text { centre }\end{array}$ & $11(9,5 \%)$ & $25(21,6 \%)$ & $22(19,0 \%)$ & $23(19,8 \%)$ & $13(11,2 \%)$ & $21(18,1 \%)$ \\
\hline
\end{tabular}

\section{Efektivitas kegiatan untuk menjaga berat badan}

Efektivitas kegiatan dalam menjaga berat badan, mayoritas responden menyatakan sangat setuju untuk melakukan kegiatan olahraga $(65,5 \%)$ dan mengatur pola makan (57,7\%). Menurut Bray dkk. (2016) dalam Management of Obesity, aktivitas yang dapat dilakukan untuk menangani kondisi obesitas yaitu perubahan perilaku hidup sehat, pengaturan pola makan, meningkatkan aktivitas fisik, penggunaan terapi obat dan dalam beberapa kasus disarankan untuk tindakan pembedahan terutama pada penderita obesitas berat. Asupan energi yang dibutuhkan per hari untuk pria 1500 - 1800 kkal sedangkan untuk wanita 1200 1500 kkal. Penggunaan terapi obat untuk menurunkan berat badan harus diawasi secara ketat oleh tenaga kesehatan. Terdapat empat obat yang telah beredar di USA pada tahun 2012 untuk menurunkan bebat badan yaitu lorcaserin, kombinasi phentermine-topiramate (ER), kombinasi naltrexone (SR)-bupropion (SR), dan liraglutide. Namun, sebagian besar responden tidak setuju penggunaan obat dan suplemen diet, serta pembedahan (operasi) dilakukan untuk menjaga berat badan (Tabel 3).

\section{Penanganan obesitas}

Sekitar 55,2\% responden percaya bahwa perawatan efektif untuk obesitas memerlukan kerja sama antar tenaga kesehatan profesional dan juga $50,00 \%$ responden percaya perlu adanya kerjasama antara tenaga kesehatan dengan individu yang bersangkutan. Keefektifan ini seperti yang ditunjukkan pada The Lifestyle Challenge Program di Amerika dimana apoteker dapat berkontribusi dalam tim multi disiplin yang berperan dalam promosi kesehatan dan pelayanan konseling secara individual dan telah didukung bukti klinis. Program ini dilaksanakan oleh apoteker bersama dokter ahli gizi, psikolog perilaku, dan ahli fisiologi olahraga. Peserta yang mengikuti program ini menunjukkan penurunan berat badan dan peningkatan kualitas hidup yang berhubungan dengan kesehatan, kebiasaan makan dan gejala depresi (Um dkk., 2013). Selain itu sebagian besar responden setuju bahwa dalam menjaga berat badan dibutuhkan penggunaan lebih dari satu metode pada Tabel 4 .

Tabel 3. Presepsi responden tentang efektivitas kegiatan

\begin{tabular}{lccccc}
\hline \multirow{2}{*}{ Efektivitas } & \multicolumn{5}{c}{ Pendapat } \\
\cline { 2 - 6 } & $\begin{array}{c}\text { Sangat Tidak } \\
\text { Setuju }\end{array}$ & Tidak Setuju & Netral & Setuju & Sangat Setuju \\
\hline $\begin{array}{l}\text { Olahraga } \\
\text { Konsultasi dengan ahli } \\
\text { gizi }\end{array}$ & $1(0,0 \%)$ & $0(0,0 \%)$ & $5(4,3 \%)$ & $35(30,2 \%)$ & $76(65,5 \%)$ \\
$\begin{array}{l}\text { Penggunaan obat } \\
\begin{array}{l}\text { Penggunaan suplemen } \\
\text { diet }\end{array}\end{array}$ & $28(24,1 \%)$ & $49(42,2 \%)$ & $19(16,4 \%)$ & $19(16,4 \%)$ & $1(0,9 \%)$ \\
$\begin{array}{l}\text { Pengaturan pola } \\
\text { makan }\end{array}$ & $24(20,7 \%)$ & $39(33,6 \%)$ & $25(21,6 \%)$ & $25(21,6 \%)$ & $3(2,6 \%)$ \\
$\begin{array}{l}\text { Penggunaan lebih dari } \\
\text { satu metode di atas }\end{array}$ & $1(0,9 \%)$ & $0(0,0 \%)$ & $5(4,3 \%)$ & $50(43,1 \%)$ & $60(51,7 \%)$ \\
\hline
\end{tabular}


Tabel 4. Persepsi responden tentang keterlibatan tenaga kesehatan dan diri sendiri dalam penanganan obesitas

\begin{tabular}{|c|c|c|c|c|c|}
\hline \multirow[b]{2}{*}{$\begin{array}{l}\text { Yang Diperlukan untuk } \\
\text { Menangani Obesitas }\end{array}$} & \multicolumn{5}{|c|}{ Pendapat } \\
\hline & $\begin{array}{l}\text { Sangat Tidak } \\
\text { Setuju }\end{array}$ & Tidak Setuju & Netral & Setuju & Sangat Setuju \\
\hline $\begin{array}{l}\text { Kerjasama antar tenaga } \\
\text { kesehatan }\end{array}$ & $1(0,9 \%)$ & $7(6,0 \%)$ & $15(12,9 \%)$ & $64(55,2 \%)$ & $29(25,0 \%)$ \\
\hline $\begin{array}{l}\text { Kerjasama antara } \\
\text { tenaga kesehatan dan } \\
\text { individu }\end{array}$ & $1(0,9 \%)$ & $3(2,6 \%)$ & $18(15,5 \%)$ & $58(50,0 \%)$ & $36(31,0 \%)$ \\
\hline
\end{tabular}

\section{Kondisi responden}

Sebanyak $44,8 \%$ responden sangat setuju dan $44,0 \%$ setuju bahwa makanan sehat dapat mengurangi resiko obesitas. Hal ini menunjukkan bahwa masyarakat mengerti bahwa dengan mengkonsumsi makanan yang sehat dapat mengurangi resiko obesitas. Sebanyak 26,7\% responden sangat setuju dan $47,4 \%$ setuju bahwa penggunaan obat diet secara rutin memberikan efek negatif yang menunjukkan bahwa masyarakat sudah mengetahui hal tersebut. Meskipun masyarakat paham bahwa makanan yang sehat dapat mengurangi resiko obesitas, tetapi masih banyak masyarakat yang tidak menerapkan hal tersebut, ditunjukkan dari data responden yang merasa bahwa makanan yang dimakan tidak selalu makanan sehat (Tabel 5).

Tabel 5. Presepsi responden tentang makanan dan obat untuk menjaga berat badan

\begin{tabular}{|c|c|c|c|c|c|}
\hline \multirow[b]{2}{*}{ Presepsi } & \multicolumn{5}{|c|}{ Pendapat } \\
\hline & $\begin{array}{c}\text { Sangat Tidak } \\
\text { Setuju }\end{array}$ & Tidak Setuju & Netral & Setuju & $\begin{array}{l}\text { Sangat } \\
\text { Setuju }\end{array}$ \\
\hline $\begin{array}{l}\text { Makanan sehat dapat } \\
\text { mengurangi resiko obesitas }\end{array}$ & $0(0,0 \%)$ & $1(0,9 \%)$ & $12(10,3 \%)$ & $51(44,0 \%)$ & $52(44,8 \%)$ \\
\hline $\begin{array}{l}\text { Makanan yang saya makan } \\
\text { selalu sehat }\end{array}$ & $14(12,1 \%)$ & $56(48,3 \%)$ & $36(31,0 \%)$ & $10(8,6 \%)$ & $10(8,6 \%)$ \\
\hline $\begin{array}{l}\text { Penggunaan obat diet secara } \\
\text { rutin memberikan efek } \\
\text { negatif }\end{array}$ & $5(4,3 \%)$ & $9(7,8 \%)$ & $16(13,8 \%)$ & $55(47,4 \%)$ & $31(26,7 \%)$ \\
\hline
\end{tabular}

\section{Pengalaman melihat dan menggunakan pelayanan dan produk healthy weight management}

Sebagian besar responden pernah melihat pelayanan atau produk terkait badan yang sehat di apotek seperti pengukuran berat badan $(83,6 \%)$, pengukuran tinggi badan $(65,5 \%)$ pengukuran tekanan darah $(68,1 \%)$, pengukuran gula darah $(66,4 \%)$, pengukuran kolesterol $(55,2 \%)$, dan suplemen penurun berat badan $(61,2 \%)$. Namun meskipun responden sudah pernah melihat pelayanan atau produk terkait berat badan yang sehat, masih sedikit yang menggunakan pelayanan atau produk tersebut kecuali pelayanan pengukuran berat badan $(66,4 \%)$ dan pengukuran tinggi badan $(50,0 \%)$ (Tabel 6).

Tabel 6. Pengalaman responden yang terkait dengan pelayanan dan produk healthy weight management di apotek

\begin{tabular}{lcc}
\hline \multicolumn{1}{c}{ Pelayanan dan Produk di Apotek } & Pernah Melihat & Pernah Menggunakan \\
\hline Pengukuran berat badan & $97(83,6 \%)$ & $77(66,4 \%)$ \\
Pengukuran tinggi badan & $76(65,5 \%)$ & $58(50,0 \%)$ \\
Pengukuran tekanan darah & $79(68,1 \%)$ & $33(28,4 \%)$ \\
Pengukuran gula darah & $77(66,4 \%)$ & $35(30,2 \%)$ \\
Pengukuran kolesterol & $64(55,2 \%)$ & $28(24,1 \%)$ \\
Produk dan bahan penurun berat badan & $38(32,8 \%)$ & $16(13,8 \%)$ \\
Suplemen penurun berat badan & $71(61,2 \%)$ & $42(36,2 \%)$ \\
Informasi produk & $56(48,3 \%)$ & $23(19,8 \%)$ \\
\hline
\end{tabular}


Tabel 7. Jenis dan frekuensi aktifitas fisik yang dilakukan responden terkait healthy weight management

\begin{tabular}{|c|c|c|c|c|c|}
\hline $\begin{array}{c}\text { Aktifitas yang } \\
\text { Dilakukan dalam } \\
\text { Seminggu }\end{array}$ & Tidak Pernah & $1 \mathrm{x}$ Seminggu & $2 \times$ Seminggu & $3 \mathrm{x}$ Seminggu & $>3 x$ Seminggu \\
\hline Lari & $45(38,8 \%)$ & $45(38,8 \%)$ & $8(6,9 \%)$ & $10(8,6 \%)$ & $8(6,9 \%)$ \\
\hline Jalan Kaki & $32(27,6 \%)$ & $9(7,8 \%)$ & $14(12,1 \%)$ & $11(9,5 \%)$ & $49(42,2 \%)$ \\
\hline Berenang & $76(65,5 \%)$ & $25(21,6 \%)$ & $10(8,6 \%)$ & $3(2,6 \%)$ & $2(1,7 \%)$ \\
\hline Bersepeda & $75(64,7 \%)$ & $24(20,7 \%)$ & $6(5,2 \%)$ & $8(6,9 \%)$ & $3(2,6 \%)$ \\
\hline Fitness & $47(40,5 \%)$ & $14(12,1 \%)$ & $15(12,9 \%)$ & $18(15,5 \%)$ & $22(19,0 \%)$ \\
\hline Senam/Yoga & $32(27,6 \%)$ & $22(19,0 \%)$ & $25(21,6 \%)$ & $21(18,1 \%)$ & $16(13,8 \%)$ \\
\hline
\end{tabular}

Tabel 8. Sikap responden terhadap apoteker tentang pelayanan healthy weight management

\begin{tabular}{lccc}
\hline \multicolumn{1}{c}{$\begin{array}{c}\text { Respon Penerimaan Responden tentang Pelayanan } \\
\text { oleh Apoteker }\end{array}$} & Tidak & Ya & Tidak Tahu \\
\hline $\begin{array}{l}\text { Perlukah apoteker menyediakan layanan kesehatan } \\
\text { menjaga berat badan yang sehat? }\end{array}$ & $11(9,5 \%)$ & $100(86,2 \%)$ & $5(4,3 \%)$ \\
$\begin{array}{l}\text { Apakah apoteker berkompeten dalam menangani } \\
\text { pasien yang } \text { overweight dan obesitas? }\end{array}$ & $28(24,1 \%)$ & $57(49,1 \%)$ & $31(26,7 \%)$ \\
$\begin{array}{l}\text { Apakah masyarakat akan menggunakan pelayanan } \\
\text { yang disediakan oleh apoteker? }\end{array}$ & $16(13,8 \%)$ & $79(68,1 \%)$ & $21(18,1 \%)$ \\
$\begin{array}{l}\text { Apakah apoteker akan menyediakan waktu untuk } \\
\text { memberikan pelayanan menjaga berat badan yang } \\
\text { sehat? }\end{array}$ & $26(22,4 \%)$ & $67(57,8 \%)$ & $23(19,8 \%)$ \\
$\begin{array}{l}\text { Perlukah masyarakat membayar untuk mendapatkan } \\
\text { pelayanan menjaga kesehatan berat badan? }\end{array}$ & $47(40,5 \%)$ & $56(48,3 \%)$ & $13(11,2 \%)$ \\
$\begin{array}{l}\text { Apakah anda bersedia menunggu 30 menit untuk } \\
\text { mendapatkan pelayanan menjaga berat badan yang } \\
\text { sehat dari apoteker? }\end{array}$ & $39(33,6 \%)$ & $63(54,3 \%)$ & $13(11,2 \%)$ \\
$\begin{array}{l}\text { Apakah anda menginginkan pelayanan tersebut } \\
\text { diberikan di Ruang terpisah? }\end{array}$ & $13(11,2 \%)$ & $97(83,6 \%)$ & $6(5,2 \%)$ \\
\hline
\end{tabular}

\section{Aktivitas fisik}

Aktivitas fisik yang sering dilakukan responden seperti lari $(61,2 \%)$, jalan kaki $(72,4 \%)$, fitness $(59,5 \%)$, dan senam/yoga $(72,4 \%)$ dengan frekuensi hingga tiga kali seminggu. Aktivitas fisik moderat selama 30 menit dilakukan setiap hari dalam seminggu atau lebih dari 20 menit minimal tiga hari dalam seminggu secara teratur mampu menjaga berat badan pada penderita obesitas, meningkatkan kekuatan dan fleksibilitas otot (Lowry dkk., 2000). Responden sebagian besar tidak melakukan aktivitas fisik seperti berenang $(65,5 \%)$ dan bersepeda $(64,7 \%)$ (Tabel 7).

\section{Respon peneriman responden tentang pelayanan apoteker}

Meskipun apoteker diprioritaskan nomer 5 oleh responden namun sebanyak $86,2 \%$ responden menyatakan bahwa apoteker perlu menyediakan layanan menjaga berat badan yang sehat (Tabel 8). Dalam sistem pelayanan kesehatan di Australia, apoteker telah berkontribusi untuk promosi kesehatan berupa gaya hidup sehat dan penyedia pelayanan healthy weight management. Program pelatihan healthy weight management diperlukan apoteker untuk menjaga kualitas dan konsistensi pelayanan (Um dkk, 2013). Sebanyak 49,1\% responden berpendapat bahwa apoteker berkompeten dalam menangani overweight dan obesitas. Selain itu menurut responden $(68,1 \%)$, ada harapan masyarakat bahwa apotek memberi pelayanan healthy weight management. Responden sejumlah $57,8 \%$ yakin bahwa apoteker akan menyediakan waktu untuk memberikan pelayanan tersebut. Sebanyak 48,3\% responden menyatakan perlu membayar untuk mendapatkan pelayanan tersebut dan 40,5\% lainnya menyatakan tidak perlu membayar untuk mendapat pelayanan tersebut. Kemudian, sebagian besar responden bersedia menunggu hingga 30 menit untuk mendapatkan pelayanan tersebut. Hampir setiap responden menginginkan pelayanan tersebut dilakukan di ruangan yang terpisah karena butuh privasi (Tabel 8). 
Responden juga berpendapat obat diet memberikan efek negatif sehingga kurang efektif dalam mengatur berat badan. Meskipun responden sudah memahami pentingnya olahraga dalam mengatur berat badan, tetapi tidak sedikit responden yang jarang melakukan aktifitas fisik atau olah raga. Responden pernah melihat fasilitas healthy weight management $\mathrm{di}$ apotek namun tidak semua menggunakan fasilitas tersebut.

\section{KESIMPULAN}

Dari penelitian ini disimpulkan responden berpendapat bahwa kegiatan olahraga, pengaturan pola makan dengan makanan yang sehat, kerjasama antara tenaga kesehatan dan individu efektif mengatur berat badan. Menurut responden, apoteker berkompeten dalam healthy weight management dan perlu menyediakan pelayanan tersebut, namun responden belum memprioritaskan apoteker dalam berkonsultasi mengenai healthy weight management.

\section{UCAPAN TERIMA KASIH}

Kelompok 4 kelas A Farmasi Masyarakat Fakultas Farmasi Universitas Airlangga angkatan 2015 mengucapkan terima kasih kepada Ibu Elida Zairina, S.Si., MPH., Ph.D., Apt. selaku dosen pembimbing, responden, serta semua pihak yang terlibat atas dukungan penuh selama melakukan penelitian ini.

\section{DAFTAR PUSTAKA}

Almatsier, S. (2004). Prinsip Dasar Ilmu Gizi. Jakarta: PT Gramedia Pustaka Utama.

Asmelashe, G. D., Binega, M. G. \& Asrade, A. S. (2017). Practice and Barriers towards Provision of Health Promotion Services among Community Pharmacists in Gondar, Northwest Ethiopia. BioMed Research International; 2017; 1-6.

Behan, D. F. \& Cox, S. H. (2010). Obesity and its Relation to Mortality and Morbidity Costs. Manitoba: Society of Actuaries.

Bray, G. A., Frühbeck, G. \& Ryan, D. H., Wilding, J. P. (2016). Management of Obesity. Lancet; 387; 1947-1956.

Brener, N. D., Eaton, D. K., Lowry, R. \& McManus, T. (2004). The Association between Weight Perception and BMI among High School Students. Obesity Research; 12; 1866-1874.

Chiolero, A., Faeh, D., Paccaud, F. \& Cornuz, J. (2008). Consequences of Smoking for Body Weight, Body Fat Distribution. The American
Jounal of Clinical Nutrition; 87; 801-809.

Elliott, J. P., Harrison, C., Konopka, C., Wood, J., Marcotullio, N., Lunney, P., Skoner, D. \& Gentile, D. (2015). Pharmacist-led Screening Program for an Inner-City Pediatric Population. Journal of the American Pharmacists Association; 55; 413-418.

Guallar-Castillón, P., Rodríguez-Artalejo, F., Fornés, N. S., Banegas, J. R., Etxezarreta, P. A., Ardanaz, E., Barricarte, A., Chirlaque, M. D., Iraeta, M. D., Larrañaga, N. L., Losada, A., Mendez, M., Martínez, C., Quirós, J. R., Navarro, C., Jakszyn, P., Sánchez, M. J., Tormo, M. J. \& González, C. A. (2007). Intake of Fried Foods is Associated with Obesity in the Cohort of Spanish Adults from the European Prospective Investigation into Cancer and Nutrition. American Journal of Clinical Nutrition; 86; 198-205.

Humayroh, W. (2009). Faktor Gaya Hidup dalam Hubungannya dengan Risiko Kegemukan Orang Dewasa di Provinsi Sulawesi Utara, DKI Jakarta, dan Gorontalo. Bogor :Institut Pertanian Bogor.

Lin, C. T. J., Zhang, Y., Carlton, E. D. \& Lo, S. C. (2016). 2014 FDA Health and Diet Survey. USA: US Food and Drug Administration.

Lowry, R., Galuska, D. A., Fulton, J. E., Wechsler, H., Kann, L. \& Collins, J. L. (2000). Physical Activity, Food Choice, and Weight Management Goals and Practices Among U.S. College Students. American Journal of Preventive Medicine; 18; 18-27.

Whitlock, G., Lewington, S., Sherliker, P., Clarke, R., Emberson, J., Halsey, J., Qizilbash, N., Collins, R. \& Peto, R. (2009). Body-Mass Index and Cause-Specific Mortality in 900000 Adults: Collaborative Analyses of 57 Prospective Studies. The Lancet; 373; 1083-1096.

O'Neal, K. S. \& Crosby, K. M. (2014). What is the Role of the Pharmacist in Obesity Management?. Current Obesity Reports; 3; 298-306.

Olaoye, O. R. \& Oyetunde, O. O. (2012). Perception of Weight and Weight Management Practices among Students of a Tertiary Institution in South West Nigeria. Journal of Applied Pharmaceutical Science; 2; 81-84.

Rimbawan \& Siagian, A. (2004). Indeks Glikemik Pangan. Bogor: Penebar Swadaya.

Um, I. S., Armour, C., Krass, I., Gill, T. \& Chaar, B. B. 
(2013). Weight Management in Community Pharmacy: What Do the Experts Think?. International Journal of Clinical Pharmacy; 35; $447-454$.
Verma, R. K. (2018). Perceptions of the Malaysian General Public on Community Pharmacy-Based Weight Management Services. Journal of Pharmaceutical Policy and Practice; 11; 17. 